\title{
Supervisi Akademik untuk Meningkatkan Kemampuan Literasi Digital Guru SMP Negeri 2 Bungursari
}

\author{
Elin Herlina \\ Pengawas SMP Dinas Pendidikan Kabupaten Purwakarta \\ elinwaspwk@gmail.com
}

\begin{abstract}
Abstrak
Proses pembelajaran harus melibatkan komponen tujuan, media, bahan, dan metode pembelajaran, alat penilaian, serta kemampuan guru dalam memamfaatkan aplikasi digital (literasi digital) untuk memperkaya serta membuat pembelajaran menjadi lebih menarik minat belajar siswa. Penelitian ini bertujuan untuk meningkatkan kemampuan guru SMP Negeri 2 Bungursari Kabupaten Purwakarta dalam membuat media video pembelajaran menggunakan aplikasi digital, khususnya inshot. Metode penelitian yang digunakan adalah penelitian tindakan sekolah, yaitu melaksanakan pembinaan bagi sekelompok guru di suatu sekolah, melalui beberapa siklus, mengunakan sistem spiral refleksi model Kemmis dan Mc Taggart yang dimodifikasi. Strategi/Metode/Teknik Pembinaan yang digunakan adalah supervisi akademik multi metode. Pada siklus 1 menggunakan Observasi-Refleksi-Rekomendasi, dan Focused Group Discussion, sedangkan pada siklus 2 menggunakan IHT, Focused Group Discussion, serta Observasi-Refleksi-Rekomendasi. Hasil penelitian menunjukkan bahwa setelah dilaksanakan supervisi akademik multi metode, kemampuan guru SMP Negeri 2 Bungursari Kabupaten Purwakarta dalam media pembelajaran video pembelajaran menggunakan aplikasi inshot, sudah menunjukkan adanya peningkatan, dari siklus I ke Siklus II. Siklus II mengakhiri pembinaan, dengan indikator skor guru minimal 80.00 sudah diatas $85 \%$, yaitu sebesar $100 \%$.
\end{abstract}

Kata Kunci: Supervisi akademik, kemampuan literasi digital, media video pembelajaran

\begin{abstract}
The learning process must involve the objective components, media, materials, and learning methods, assessment tools, and the ability of teachers to utilize the application of digital (digital literacy) to enrich and make learning more attractive to students' learning interests. This study aims to improve the ability of teachers at Bungursari Middle School 2 Purwakarta Regency in making learning media using technology applications, especially inshot. The research method used is school action research, which is providing guidance for a group of teachers in a school, through several cycles, using a modified Kemmis and Mc Taggart model spiral spiral system. The Strategy / Method / Coaching Technique used is multi-method academic supervision. In cycle 1 using Observation-ReflectionRecommendations, and Focused Group Discussion, while in cycle 2 using IHT,
\end{abstract}


Focused Group Discussion, and Observation-Reflection-Recommendations. The results showed that after multi-method academic supervision, the teacher's ability of Bungursari Middle School 2 in Purwakarta Regency in learning video learning media using inshot applications, had shown an increase, from cycle I to Cycle II. Cycle II ends coaching, with a teacher score indicator of at least 80.00 already above $85 \%$, which is equal to $100 \%$. Keywords: Academic supervision, technological literacy skills, media learning video

\section{PENDAHULUAN}

Proses pembelajaran harus melibatkan komponen: tujuan, media, bahan, dan metode pembelajaran, serta alat penilaian (Arikunto, 2003; Udin, 1992; dan Winkell, 1993). Jika salah satu komponen tidak ada maka proses pembelajaran kurang berhasil (Udin, 1992 dan Sudjana, 2001). Namun fakta dilapangan sebagian guru selalu menggunakan metode pembelajaran konvensional yang bersifat satu arah. Kondisi tersebut diperparah dengan adanya data, masih banyak guru yang belum memamfaatkan aplikasi digital untuk memperkaya serta membuat pembelajaran menjadi lebih menarik minat belajar siswa (Newman et all, 1998; Hobbs, 1998; dan Harris et all, 1995). Pada saat ini aplikasi digital berkembang sangat pesat.

Aplikasi digital akan dengan mudahnya diperoleh dari media internet termasuk informasi media pembelajaran, materi, model, dan metode pembelajaran. Jadi bisa dibanyangkan jika guru tidak menguasai aplikasi digital maka guru tersebut, akan mengalami kesulitan untuk meningkatkan kualitas proses pembelajaran (Barbara et all, 2008; Elain, 2000; Marfuah, 2011; \& Retno, 2003). Untuk mencapai proses pembelajaran yang berkualitas, maka guru harus bertanggung jawab dan berinitiatif untuk mengenali kebutuhan belajar siswa, menemukan sumber-sumber informasi untuk dapat menjawab kebutuhannya, membangun serta mempresentasikan pengetahuannya berdasarkan kebutuhan serta sumber-sumber yang ditemukannya. Dengan anggapan bahwa tiap peserta didik adalah individu yang unik, proses, materi dan metode belajar disesuaikan secara fleksibel dengan minat, bakat, kecepatan, gaya serta strategi belajar dari tiap peserta didik. Tersedianya pilihan-pilihan bebas ini bertujuan untuk menggali motivasi intrinsik dari dalam dirinya sendiri untuk belajar sesuai dengan kebutuhannya secara individu, bukan kebutuhan yang diseragamkan (Barbara, et al, 2008; Marfuah; 1989 \& Retno, 2003). Pelaksaan pembinaan tersebut akan optimal jika guru telah menguasai terlebih dahulu aplikasi digital dengan menggunakan internet.

Kajian penggunaan aplikasi digital dalam pembelajaran terbukti meningkatkan hasil pembelajaran. Beberapa penelitian yang menunjukkan hal tersebut diantaranya: (1) Hernani \& Ahmad (2010) menyimpulkan bahwa keterampilan proses siswa SMP kelas VII meningkat setelah menggunakan pembelajaran berbasis literasi digital; (2) Bella ( (2018) menyimpulkan bahwa penerapan literasi digital dan teknologi memiliki pengaruh yang signifikan terhadap peningkatan pembelajaran siswa SMP Negeri 6 Banda Aceh, dan (3) Husain (2004) menyimpulkan bahwa penggunaan teknologi informasi dan teknologi sebagai media pembelajaran meningkatkan motivasi belajar siswa SMA, dan (4) Djuniar dkk (2015) menyimpulkan terdapat perbedaan hasil belajar 
antara siswa yang belajar menggunakan pembelajaran berbasis literasi dibanding dan yang belajar menggunakan pembelajaran konvensional. Salah satu upaya untuk meningkatkan kualitas proses dan hasil pembelajaran yang dilakukan guru, diantaranya dengan meningkatkan kemampuan guru tersebut dalam membuat media pembelajaran berbasis aplikasi digital, khususnya aplikasi inshot. Untuk mencapai tujuan tersebut perlu adanya pembinaan yang dilakukan oleh pengawas sekolah dengan menerapkan metode atau model supervisi yang bermutu (Dirjen PMPTK, 2008 dan Sujana dkk, 2011). Hal inilah yang mendorong peneliti telah melaksanakan penelitian tindakan sekolah dengan menerapkan supervisi akademik multi metode untuk meningkatkan kemampuan guru SMP Negeri 2 Bungursari Kabupaten Purwakarta dalam membuat media pembelajaran video pembelajaran melalui aplikasi inshot

\section{METODOLOGI PENELITIAN}

Metode penelitian yang digunakan adalah Penelitian Tindakan Sekolah yaitu melaksanakan pembinaan bagi sekelompok guru di suatu sekolah, melalui beberapa siklus, mengunakan sistem spiral refleksi model Kemmis dan Mc Taggart yang dimodifikasi (Sukidin dkk, 2002; Sumarno, 2005; \& Wiriaatmadja, 1999), dengan tahapan mulai dari merencanakan pembinaan setiap siklus, pelaksanan pembinaan setiap siklus, observasi pelaksanaan dan refleksi pembinaan setiap siklus, yang dilakukan dari siklus I sampai siklus II dan seterusnya sampai diperoleh rekomendasi kemampuan guru pada siklus terakhir tuntas. Indikator ketuntasan apabila telah mencapai $85 \%$ subjek daya serapnya $\geq 70 \%$ (Depdikbud RI, 1994, dalam Sudjana, 2001 dan Arikunto, 2003).

\subsection{Strategi / Metode / Teknik Pembinaan}

Strategi/Metode/Teknik Pembinaan yang digunakan pada siklus 1 adalah Observasi-Refleksi-Rekomendasi, Focused Group Discussion, sedangkan pada siklus 2 adalah IHT, Focused Group Discussion, Observasi-RefleksiRekomendasi

\subsection{Setting / Lokasi / Subyek Penelitian}

Secara garus besar, prosedur siklus dilakukan melalui kegiatan perencanaan (plan), siklus (act), observasi (observe) dan refleksi (reflect).

Prosedur penelitian tersebut dilaksanakan dalam lima tahapan yaitu :

1) Rencana tindakan pembinaan, yaitu merumuskan rencana pembinaan setiap kali akan melaksanakan pembinaan serta fokus yang akan diamati selama pelaksanaan pembinaan

2) Penilaian terhadap keterampilan guru dalam membuat materi pelajaran dalam bentuk power point

3) Observasi pembinaan guru, adalah proses mendokumentasikan pengaruh, kendala, tindakan pembinaan, serta persoalan yang mungkin ada, pada saat pembinaan berlangsung. Observasi dibantu oleh observer (rekan kepala sekolah) sehingga observasi akan menjadi efektif dan efisien, observer mengobservasi peneliti dan guru selama pelaksanaan pembinaan, penelitipun mengamati proses serta kegiatan yang dilaksanakan oleh guru, serta mencatat 
kendala-kendala yang dihadapi guru. Hasil observasi itu mendasari refleksi untuk siklus yang telah dilakukan dan dijadikan pertimbangan untuk menyusun rencana siklus selajutnya

4) Refleksi, yaitu menjelaskan setiap efek-efeknya dan kegagalan pelaksanaan. Rekomendasi ini hasil kolaborasi antara guru, peneliti dan observer serta dengan kepala sekolah, untuk mendiskusikan kelebihan dan kekurangan serta pengaruhnya dalam kegiatan pembinaan pada setiap siklus selama penelitian dilaksanakan Diskusi balikan, dilakukan antara guru, peneliti, observer serta dengan kepala sekolah, terhadap hasil observasi. Hasil diskusi balikan merupakan refleksi dari hasil observasi yang kemudian di interpretasi dan dijadikan rencana untuk memperbaiki kekurangan-kekurangan yang ada pada siklus yang telah dilaksanakan, untuk diterapkan pada siklus selanjutnya

\subsection{Subyek dan Waktu Penelitian}

Subyek penelitian dalam penelitian ini adalah guru SMP Negeri 2 Bungursari Kabupaten Purwakarta. Penelitian telah dilaksanakan pada tanggal 9 Juli 11 Agustus 2018

\subsection{Instrumen Penelitian}

Untuk memperoleh data yang diharapkan, maka dalam penelitian ini digunakan instrumen sebagai berikut: (1) rencana pelaksanaan pembinaan; (2) pedoman observasi aktivitas guru; (3) daftar chek

aktivitas guru; (4) Instrumen evaluasi guru dalam membuat media pembelajaran video pembelajaran; format diskusi balikan; dan

(5) format observasi pembinaan;

(7) daftar hadir guru

\section{HASIL DAN PEMBAHASAN}

\subsection{Hasil}

\section{1) Persiapan dan Pelaksaan Pembinaan dari Siklus I - II}

Sebelum melaksanakan penelitian siklus I peneliti selalu merencanakan dan mengecek semua aspek meliputi: (1) rencana pelaksanaan pembinaan; (2) pedoman observasi aktivitas guru; (3) daftar chek aktivitas guru; (4) instrumen evaluasi guru dalam membuat media pembelajaran video pembelajaran; (5) format observasi pembinaan; (6) format diskusi balikan; dan (7) daftar hadir guru

Setiap pelaksanaan penelitian, peneliti selalu melakukan diskusi balikan untuk mendapatkan informasi kekurangan-kekurangan yang ada sehingga disempurnakan pada siklus selanjutnya. Catatan lapangan (lembar observasi) dan

lembar diskusi balikan telah mencatat perubahan yang terjadi.

Perubahan yang terjadi tidak hanya dari cara hasil pembinaan, tetapi dilihat juga dilihat dari proses pembinaannya, yaitu aktivitas guru. Aktivitas guru dan perolehan skor guru, selama pembinaan dari siklus I sampai siklus II telah mengalami perbaikan dan peningkatan. 


\section{2) Perubahan Aktivitas Guru dari Siklus 1 - Siklus II}

Proses pembinaan pada siklus II telah memperlihatkan adanya peningkatan aktivitas guru dibanding pada siklus I, mulai dari menginstal inshot, masuk ke dalam aplikasi inshot, masuk ke aplikasi video, membuat video pembelajaran dan mengedit video pembelajaran. Aktifitas guru selama pembinaan pada siklus II dapat dilihat pada Tabel 1

Tabel 1

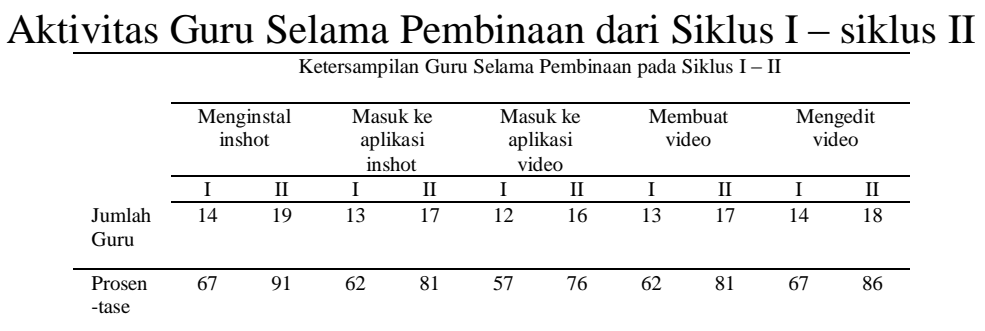

Data pada Tabel 1 menunjukkan bahwa kemampuan guru dalam menginstal inshot dengan terampil dari siklus I sampai siklus II mengalami peningkatan. Pada siklus I guru yang benar-benar terampil berjumlah 14 orang $(66.67 \%)$, dan pada siklus II berjumlah 19 orang $(90.48 \%)$.

Kemampuan guru dalam masuk ke dalam aplikasi inshot dengan terampil dari siklus I sampai siklus II mengalami peningkatan. Pada siklus I guru yang benarbenar terampil berjumlah 13 orang (61.90\%), dan pada siklus II berjumlah 17 orang $(80.95 \%)$.

Berdasarkan data pada Tabel 1 kemampuan guru dalam melakukan add folder pada library dengan terampil dari siklus I sampai siklus II mengalami peningkatan. Pada siklus I guru yang benar-benar terampil berjumlah 12 orang (57.14\%), dan pada siklus II berjumlah 16 orang (76.19\%).

Kemampuan guru dalam membuat video pembelajaran dengan terampil dari siklus I sampai siklus II mengalami peningkatan. Pada siklus I guru yang benarbenar terampil berjumlah 13 orang (61.90\%), dan pada siklus II berjumlah 17 orang $(80.95 \%)$.

Berdasarkan data pada Tabel 1 kemampuan guru dalam membuat fiturfitur pembelajaran yang akan digunakan dengan terampil dari siklus I sampai siklus II mengalami peningkatan. Pada siklus I guru yang benar-benar terampil berjumlah 14 orang (66.67\%), dan pada siklus II berjumlah 18 orang $(85.71 \%)$.

\section{3) Skor Guru dari Siklus I - II}

Berdasarkan hasil skor guru dalam membuat media pembelajaran video pembelajaran selama pembinaan, menunjukkan adanya peningkatan skor guru pada siklus II dibanding siklus I. Peningkatan skor guru dapat dilihat pada Tabel 2 
Tabel 2

Skor Guru dari Siklus I - II

\begin{tabular}{|c|c|c|c|}
\hline \multirow{2}{*}{ No } & \multirow{2}{*}{ Kode Guru } & \multicolumn{2}{|c|}{ Nilai } \\
\hline & & Siklus I & Siklus II \\
\hline 1 & $\mathrm{AA}$ & 80 & 90 \\
\hline 2 & $\mathrm{AB}$ & 60 & 70 \\
\hline 3 & $\mathrm{AC}$ & 60 & 70 \\
\hline 4 & $\mathrm{AD}$ & 60 & 70 \\
\hline 5 & $\mathrm{AE}$ & 80 & 80 \\
\hline 6 & $\mathrm{AF}$ & 80 & 90 \\
\hline 7 & $\mathrm{AG}$ & 70 & 80 \\
\hline 8 & $\mathrm{AH}$ & 80 & 90 \\
\hline 9 & $\mathrm{AI}$ & 60 & 70 \\
\hline 10 & $\mathrm{AJ}$ & 70 & 80 \\
\hline 11 & AK & 50 & 60 \\
\hline 12 & $\mathrm{AL}$ & 60 & 70 \\
\hline 13 & $\mathrm{AM}$ & 60 & 60 \\
\hline 14 & AN & 80 & 90 \\
\hline 21 & $\mathrm{AO}$ & 70 & 80 \\
\hline 16 & $\mathrm{AP}$ & 80 & 90 \\
\hline 17 & AQ & 60 & 70 \\
\hline 18 & $\mathrm{AR}$ & 70 & 80 \\
\hline 19 & AS & 50 & 60 \\
\hline 20 & AT & 80 & 90 \\
\hline \multirow[t]{3}{*}{21} & $\mathrm{AU}$ & 70 & 80 \\
\hline & Rerata & 68.10 & 77.14 \\
\hline & DSK & $57.14 \%$ & $85.71 \%$ \\
\hline
\end{tabular}

Berdasarkan data pada Tabel 2, dapat dijelaskan:

1) Pada Siklus I, skor tertinggi adalah 80.00 , terendah 50.00 dan rata-ratanya adalah 68.10 serta jumlah guru yang mengalami ketuntasan belajarnya sebanyak 12 orang (57.14\%).

2) Pada Siklus II, nilai rata-rata harian tertinggi adalah 90.00, terendah 60.00 dan rata-ratanya adalah 77.14 serta jumlah guru yang mengalami ketuntasan belajarnya sebanyak 18 orang $(85.71 \%)$.

\subsection{Pembahasan.}

1) Pengaruh Pembinaan Terhadap Peningkatan Aktivitas Guru dari Siklus I - Siklus II

Hasil observasi proses pembinaan dari siklus I sampai Siklus II, menggambarkan bahwa aktivitas guru menunjukan pola yang aktif, serta antusias mengikuti setiap sesi pembinaan.

Hampir semua guru berperan aktif membuat media pembelajaran video pembelajaran, mulai dari menginstal inshot, masuk ke dalam aplikasi inshot, masuk ke aplikasi video, membuat video pembelajaran dan mengedit video pembelajaran. Walaupun pada awalnya banyak yang belum terampil tetapi pada siklus II sudah menunjukkan kemajuan yang sangat pesat

2) Pengaruh Pembinaan terhadap Kemampuan dan Keterampilan Guru dalam Membuat media pembelajaran video pembelajaran. 
Hasil observasi proses pembinaan dari siklus I sampai siklus II, menggambarkan bahwa skor guru menunjukan adanya peningkatan. Peningkatan itu menunjukkan bahwa setiap guru telah melaksanakan dan mengikuti tahaptahap jalannya kegiatan pembinaan, serta menunjukan bahwa hampir semua guru berperan aktif mengikuti setiap sesi pembinaan yang dilakukan oleh peneliti. Sehingga pada saat dilaksanakan pengukuran kemampuan dan keterampilan guru dalam membuat media pembelajaran video pembelajaran, pada siklus II, sudah $85.71 \%$ guru memperoleh skor 70.00 ke atas.

Selain itu proses bimbingan dan arahan selama proses pembinaan yang dilakukan sudah diupayakan intensif. Sehingga guru tidak mengalami kesulitan dalam melaksanakan proses pembinaan dalam membuat media pembelajaran video pembelajaran

\section{KESIMPULAN}

Hasil proses pembinaan pada siklus I, menunjukkan bahwa aktivitas guru dalam menginstal inshot, masuk ke dalam aplikasi inshot, masuk ke aplikasi video, membuat video pembelajaran dan mengedit video pembelajaran masih perlu ditingkatkan, kemudian skor rata-rata hasil pembinaan guru, belum memuaskan yaitu 68.10. Aktivitas guru dalam siklus I, perlu ditingkatkan dan harus diperbaiki pada siklus II.

Proses pembinaan pada siklus II, menunjukkan bahwa aktivitas pembinaan guru dalam menginstal inshot, masuk ke dalam aplikasi inshot, masuk ke aplikasi video, membuat video pembelajaran dan mengedit video pembelajaran sudah menunjukkan adanya peningkatan. Skor rata-rata hasil pembinaan guru sudah meningkat menjadi 77.14, siklus II mengakhiri pembinaan, dengan indikator keaktifan guru telah diatas $70.00 \%$ dan Skor guru minimal 70.00 sudah diatas $85 \%$, yaitu sebesar $85.71 \%$

Selama proses pembinaan mulai siklus I sampai siklus II, peneliti berusaha memotivasi setiap guru dan melaksanakan bimbingan serta arahan secara intensif dan adil, supaya setiap guru berpartisifasi dalam mengikuti setiap sesi pembinaan, mulai dari menginstal inshot, masuk ke dalam aplikasi inshot, masuk ke aplikasi video, membuat video pembelajaran dan mengedit video pembelajaran

\section{DAFTAR PUSTAKA}

Arikunto, S. (2003). Dasar-Dasar Evaluasi Pendidikan. Bumi Aksara. Jakarta.

Barbara, S., et all. (2008). Vienna E-Lecturing (VEL): learning how to learn selftregulated in an internet-based blanded learning setting. International journal on e-learning. (Online) Tersedia: http://proquest.umi.com/pqdweb?index $=9 \&$ did $=2180113171 \&$ SrchMode $=$ $1 \&$ sid=1\&Fmt=6\&VInst=PROD\&VType $=$ PQD $\&$ RQT $=309 \&$ VName $=P Q$ D\&TS $=1228466890 \&$ clientId $=68516$ ( 8 November 2008$)$

Bella, E. (2018). Pengaruh Penerapan Literasi Digital \& Teknologi terhadap Peningkatan Pembelajaran Siswa di SMP Negeri 6 Banda Aceh. Skripsi. UIN Ar-Rantry Darussalam - Banda Aceh. 
Dirjen PMPTK. (2008). Metode dan

Teknik Supervisi, Jakarta

Djuniar R.H., Eny, E., dan Ira, L. (2015). Pembelajaran berbasis literasi pada materi Larutan Elektrolit dan Non Elektrolit di SMA Negeri 1 Pontianak. Tesis. Program Pascasarjana. Untan

Elain, C. (2000). New Approaches to Literacy Learning. UNESCO Consultant

Harris, Theodore L., Hoghes, Richard E. (1995). The Literacy Dictionary. Newark, Delaware: International Reading Assosia Delaware

Hernani \& Ahmad, M. (2010). Pengaruh Pembelajaran Berbasis Literasi Sains dan Teknologi terhadap Keterampilan Proses SAINS siswa SMP. Jurnal Pendidikan Matematika dan Sains Edisi I Tahun XV 2010

Hobbs, R. (1998). Instructional Practices in Media Literacy and Their Impact on

Husain, C. 2014. Pemanfaatan Teknologi Informasi dan Komunikasi dalam Pembelajaran di SMA Muhammadiyah Tarakan. Jurnal Kebijakan dan Pengembangan Pendidikan Volume 2, Nomor 2, Juli 2014; 184-192

Marfuah. M.T (2011). Edmodo: Social Network Berbasis Sekolah. Available: http://p4tkmatematika.org/2011/12/edmodo-social-network-berbasis$\underline{\text { sekolah }}$

Newman, Susan B., Roskes, Kathleen A. (1998). Children Achieving: Best Practices in Literacy. Newark, Delaware: International Reading Assosiation.

Retno. (2003). Media Pendidikan, Pengertian, Pengembangan, dan Pemanfaatannya. Rajawali. Jakarta. Students Learning. Tersedia dalam <www.interact.uoregon.edu/MediaLit/readingarticles/hobbs/inspractice.ht ml,>diakses 20 Agustus 2011.

Sudjana, (2001). Penelitian dan Penilaian Pendidikan. Sinar Baru. Jakarta.

Sujana, dkk. (2011). Buku Kerja Pengawas. Pusat Pengembangan Tenaga Kependidikan, Badan PSDM dan PMP, Kementrian Pendidikan Nasional. Jakarta

Sukidin. (2002). Manajemen Penelitian. Insan Cendikia. Jakarta.

Sumarno, U. (2005). Penelitian Siklus. Makalah. UPI. Tidak diterbitkan 
Udin S.W. (1992). Strategi Belajar Mengajar. Depdikbud. Jakarta.

Winkell, W.S. (1993). Psikologi Pengajaran. Gramedia. Jakarta

Wiriaatmadja, (1999). Penelitian Tindakan dalam Bentuk Siklus Sebagai Upaya Meningkatkan Kemahiran Profesional Dosen di Perguruan Tinggi. Jurnal

Mimbar Penelitian.

No 30/Juli.

UPI 